\title{
Antimicrobial Susceptibility, Tetracycline and Erythromycin Resistance Genes, and Multilocus Sequence Typing of Streptococcus suis Isolates from Diseased Pigs in China
}

\author{
Lei $\mathrm{CHEN}^{1)}$, Yajing $\mathrm{SONG}^{2}$, Zigong WEI ${ }^{1)}$, Hongkui $\mathrm{HE}^{1)}$, Anding $\mathrm{ZHANG}^{1,2)}$ and Meilin $\mathrm{JIN}^{1,2) *}$ \\ 1) Unit of Animal Infectious Diseases, National Key Laboratory of Agricultural Microbiology, Huazhong Agricultural University, Wuhan \\ 430000, China \\ 2) College of Veterinary Medicine, Huazhong Agricultural University, Wuhan 430000, China
}

(Received 22 June 2012/Accepted 15 December 2012/Published online in J-STAGE 28 December 2012)

ABSTRACT. Streptococcus suis (S. suis) is an emerging zoonotic pathogen causing significant economic losses in the swine industry. Here, we investigated the antimicrobial susceptibility, associated antibiotic-resistant determinants and sequence type (ST) of $S$. suis isolates from diseased pigs in China from 2008 to 2010. Serotype 2 was the most frequently observed strain ( $\mathrm{n}=95)$ among the $106 \mathrm{~S}$. suis strains collected, followed by serotypes $3(n=3), 5(n=3), 4(n=2), 7(n=1), 11(n=1)$ and $28(n=1)$. Multilocus sequence typing analysis revealed that ST1 $(\mathrm{n}=21)$ and ST7 $(\mathrm{n}=74)$ were the predominant STs, and serotype 2 was found to be significantly correlated with ST7 $(P=0.017$, Fisher's exact test $)$ and $\mathrm{CC} 1(P=0.024$, Fisher's exact test). The antimicrobial susceptibility results indicated that the antibiotic resistance rate was highest for tetracycline $(99.1 \%)$, followed by azithromycin $(68.9 \%)$, erythromycin $(67.9 \%)$, clindamycin $(67.9 \%)$, trimethoprim/ sulfamethoxazole (16\%), levofloxacin (2.8\%), chloramphenicol $(1.9 \%)$, cefaclor $(0.9 \%)$ and ceftriaxone $(0.9 \%)$. Antibiotic-resistant genes $t e t(\mathrm{M}), \operatorname{tet}(\mathrm{O}), \operatorname{tet}(\mathrm{O} / \mathrm{W} / 32 / \mathrm{O}), \operatorname{tet}(\mathrm{O} / 32 / \mathrm{O}), \operatorname{tet}(\mathrm{S}), \operatorname{tet}(\mathrm{W}), \operatorname{tet}(\mathrm{L}), \operatorname{tet}(40), \operatorname{erm}(\mathrm{B}), \operatorname{mef}(\mathrm{A} / \mathrm{E})$ and $m s r(\mathrm{D})$ could be detected, and several tandem organizations of antibiotic resistance genes were also found in this study. In conclusion, S. suis strains isolated from diseased pigs in China were less diverse and multi-drug resistant.

KEY WORDS: antimicrobial susceptibility, multilocus sequence typing, streptococcus suis.

doi: 10.1292/jvms.12-0279; J. Vet. Med. Sci. 75(5): 583-587, 2013

Streptococcus suis, an emerging zoonotic pathogen, can cause infections of both pigs, and occasionally, human beings; such infections include meningitis, septicemia, pneumonia, endocarditis and arthritis [14, 20]. Thirty-three serotypes (types 1-31, 33 and 1/2) have been described based on capsular polysaccharides, and serotype 2 is considered to be the most pathogenic as well as the most prevalent capsular type in diseased pigs. Control of the disease by antimicrobials has generally been ineffective, partly because of increased resistance by $S$. suis to antimicrobials.

Tetracycline and erythromycin are two antimicrobials that are extensively used for therapy, prophylaxis and growth promotion, and subsequently, associated resistance has been widely reported at a high rate in S. suis strains isolated from pigs and human beings $[3,10,18]$. However, mechanisms, which contribute to the tetracycline and macrolide resistance in Chinese $S$. suis strains, are still poorly understood. Besides, although several approaches have been used to characterize $S$. suis isolates from diseased pigs in limited geographic regions in China $[13,22]$, knowledge about the current epidemiological status of $S$. suis in Chin is still limited. Therefore, in this study, we investigated the antimicrobial resistance patterns, tetracycline and erythromycin resistance genes, Serotypes and STs of $S$. suis isolated from diseased pigs in central and eastern regions of China.

*Correspondence to: Jin, M., College of Veterinary Medicine, Huazhong Agricultural University, Wuhan 430000, China. e-mail: jm18328@126.com

C2013 The Japanese Society of Veterinary Science

\section{MATERIALS AND METHODS}

Bacterial strains and antimicrobial susceptibilities: All strains ( $\mathrm{n}=106)$ used in this study were obtained from samples of different tissues (lung, brain, joint, heart and blood) isolated from diseased pigs from 14 provinces in central and eastern regions of China between 2008 and 2010. Bacteria were isolated according to the procedures described in our previous study [24]. Serotyping of S. suis was performed by a coagglutination test, using commercial specific sera against serotypes 1-31, and 33 (Statens Serum institute, Copenhagen, Denmark).

Antimicrobial susceptibility testing was performed on all the 106 isolates by broth microdilution with the MicroScan Micro STREP plus 1 system (Siemens, West Sacramento, CA, U.S.A.) The antimicrobial agents tested and breakpoints were as follows: ampicillin, $8 \mu \mathrm{g} / \mathrm{ml}$; penicillin, $4 \mu \mathrm{g} / \mathrm{ml}$; cefepime, $4 \mu \mathrm{g} / \mathrm{m} l$; cefotaxime, $4 \mu \mathrm{g} / \mathrm{m} l$; ceftriaxone, $4 \mu \mathrm{g} / \mathrm{m} l$; erythromycin, $1 \mu \mathrm{g} / \mathrm{ml}$; azithromycin, $2 \mu \mathrm{g} / \mathrm{ml}$; tetracycline, $8 \mu \mathrm{g} / \mathrm{ml}$; chloramphenicol, $16 \mu \mathrm{g} / \mathrm{ml}$; clindamycin, $1 \mu \mathrm{g} / \mathrm{ml}$; levofloxacin, $8 \mu \mathrm{g} / \mathrm{m} l$; cefuroxime, $4 \mu \mathrm{g} / \mathrm{ml}$; cefaclor, $4 \mu \mathrm{g}$ / $\mathrm{ml}$; meropenem, $1 \mu \mathrm{g} / \mathrm{ml}$; trimethoprim/sulfamethoxazole, $4 / 76 \mu \mathrm{g} / \mathrm{ml}$; and amoxicillin $/ \mathrm{K}$ clavulanate, $8 / 4 \mu \mathrm{g} / \mathrm{m} l$.

S. suis was considered to be susceptible to vancomycin at a MIC of $\leq 1 \mu \mathrm{g} / \mathrm{ml}$. Susceptibility breakpoints were determined according to the Clinical and Laboratory Standards Institute guidelines from 2008 [4]. Strains for which the MICs to tetracycline and erythromycin were greater than the highest dilution included on the MicroScan panel were retested by broth microdilution to determine the precise MICs. Tetracycline and erythromycin were purchased from Sigma 
Table 1. Oligonucleotide sequences used as primers for PCR

\begin{tabular}{|c|c|c|c|c|c|}
\hline Genes & Primer & Primer sequence $\left(5^{\prime}-3^{\prime}\right)$ & Size (bp) & $\begin{array}{l}\text { Annealing } \\
\text { temp }\left({ }^{\circ} \mathrm{C}\right)\end{array}$ & Reference \\
\hline \multirow{2}{*}{$\operatorname{tet}(\mathrm{K})$} & tet(H)-F & TCGATAGGAACAGCAGTA & \multirow{2}{*}{169} & \multirow{2}{*}{54} & \multirow{2}{*}[16]{} \\
\hline & tet(H)-R & CAGCAGATCCTACTCCTT & & & \\
\hline \multirow{2}{*}{$\operatorname{tet}(\mathrm{L})$} & $\operatorname{tet}(\mathrm{L})-\mathrm{F}$ & TCGTTAGCGTGCTGTCATTC & \multirow[t]{2}{*}{267} & \multirow{2}{*}{55} & \multirow[t]{2}{*}[16]{} \\
\hline & tet( $(\mathrm{L})-\mathrm{R}$ & GTATCCCACCAATGTAGCCG & & & \\
\hline \multirow{2}{*}{$\operatorname{tet}(\mathrm{M})$} & tet(M)-F & GTGGACAAAGGTACAACGAG & \multirow{2}{*}{406} & \multirow{2}{*}{55} & \multirow{2}{*}[16]{} \\
\hline & tet(M)-R & CGGTAAAGTTCGTCACACAC & & & \\
\hline \multirow{4}{*}{$\operatorname{tet}(\mathrm{O})$} & $\operatorname{tet}(\mathrm{O})-\mathrm{F}$ & AACTTAGGCATTCTGGCTCAC & \multirow{2}{*}{515} & \multirow{2}{*}{55} & \multirow{2}{*}[16]{} \\
\hline & tet(O)-R & TCCCACTGTTCCATATCGTCA & & & \\
\hline & tetOFF2 & TTGTTTTGGGGCTATTGGAG & \multirow{2}{*}{2037} & \multirow{2}{*}{52} & \multirow{2}{*}[17]{} \\
\hline & tetOFF3 & TATATGACTTTTGCAAGCTG & & & \\
\hline \multirow{2}{*}{$\operatorname{tet}(\mathrm{S})$} & $\operatorname{tet}(\mathrm{S})-\mathrm{F}$ & CATAGACAAGCCGTTGACC & \multirow{2}{*}{667} & \multirow{2}{*}{55} & \multirow{2}{*}[16]{} \\
\hline & tet(S)-R & ATGTTTTTGGAACGCCAGAG & & & \\
\hline \multirow{2}{*}{$\operatorname{tet}(40)$} & tet(40)-F & CGGAGGAAGAGGACAAACCC & \multirow{2}{*}{446} & \multirow{2}{*}{56} & \multirow{2}{*}{ This study } \\
\hline & tet(40)-R & TAAGCCGCTGCCGATAAGAC & & & \\
\hline \multirow{2}{*}{$\operatorname{tet}(\mathrm{W})$} & tet(W)-F & ACAACGAGGACGGACACCATG & \multirow{2}{*}{323} & \multirow{2}{*}{58} & \multirow{2}{*}{ This study } \\
\hline & tet(W)-R & TTATCCCGAACAGACTGAACCAC & & & \\
\hline \multirow{2}{*}{$\operatorname{erm}(\mathrm{B})$} & $\operatorname{erm}(\mathrm{B})-\mathrm{F}$ & TGGTATTCCAAATGCGTAATG & \multirow{2}{*}{745} & \multirow{2}{*}{62} & \multirow{2}{*}[15]{} \\
\hline & $\operatorname{erm}(\mathrm{B})-\mathrm{R}$ & CTGTGGTATGGCGGGTAAGT & & & \\
\hline$m e f(\mathrm{~A} / \mathrm{E})$ & $\operatorname{mef}(\mathrm{A})-\mathrm{F}$ & CAATATGGGCAGGGCAAG & 317 & 62 & {$[5]$} \\
\hline & $\operatorname{mef}(\mathrm{A})-\mathrm{R}$ & AAGCTGTTCCAATGCTACGG & 311 & 02 & {$[10]$} \\
\hline$m s r(\mathrm{D})$ & $\mathrm{msr}(\mathrm{D})-\mathrm{F}$ & TTGGACGAAGTAACTCTG & 370 & 50 & {$[5]$} \\
\hline & $\mathrm{msr}(\mathrm{D})-\mathrm{R}$ & GCTTGGCTCTTACGTTC & $3 / 0$ & & {$[J]$} \\
\hline
\end{tabular}

Chemical Co. (St. Louis, MO, U.S.A.).The $S$. pneumoniae strain ATCC 49619 was used as a quality control.

Detection and analysis of tetracycline and erythromycin resistance determinants: Genomic DNA was extracted using the DNeasy Tissue Kit (Qiagen, Hilden, Germany), following the manufacturer's instructions. The tetracycline resistance genes $[\operatorname{tet}(\mathrm{K}), \operatorname{tet}(\mathrm{L}), \operatorname{tet}(\mathrm{M}), \operatorname{tet}(\mathrm{O}), \operatorname{tet}(\mathrm{S}), \operatorname{tet}(\mathrm{W})$ and tet(40)] and erythromycin resistance genes $[\operatorname{erm}(\mathrm{B})$, $m e f(\mathrm{~A} / \mathrm{E})$ and $m s r(\mathrm{D})]$ were amplified by PCR with genomic DNA templates. The primer pairs, the amplicon lengths and the annealing temperatures used are listed in Table 1. To determine the linkage between tetracycline and/or erythromycin resistance genes, which could be concomitantly detected, the four primer combinations associated with the possible reciprocal orientation of the two genes were used. The PCR reaction mixture (total $50 \mu l$ ) contained $0.5 \mu \mathrm{g}$ template DNA, $1 \times$ PCR buffer, 1.25 U DNA Ex Taq polymerase (Takara, Otsu, Japan), $2 \mu l$ of $10 \mathrm{mM}$ dNTPs (2.5 mM each), 0.2 $\mathrm{mM}$ of each primer and DNase-RNase-free water. PCR amplification was performed with a Mastercycler (Eppendorf AG, Wesseling, Berzdorf, Germany) under the following conditions: denaturation period at $95^{\circ} \mathrm{C}$ for $3 \mathrm{~min}$, followed by 35 cycles of $94^{\circ} \mathrm{C}$ for $30 \mathrm{sec}, \mathrm{X}^{\circ} \mathrm{C}$ for $30 \mathrm{sec}$ and $72^{\circ} \mathrm{C}$ for $1 \mathrm{~min}$ per kilobase of predicted product size, where $\mathrm{X}^{\circ} \mathrm{C}$ represents an annealing temperature appropriate for the particular primer set used. A final extension was conducted at $72^{\circ} \mathrm{C}$ for $10 \mathrm{~min}$. PCR products were visualized by agarose gel electrophoresis on $1.0 \%$ agarose in the presence of $1 \mu \mathrm{g}$ of ethidium bromide $\mathrm{m} l^{-1}$.

The presence of tetracycline and erythromycin resistance genes was confirmed based on the amplicon sizes and the sequences of the selected PCR products. The resulting DNA sequences were analyzed on the BLAST server (http://www. ncbi.nlm.nih.gov).

Multilocus sequence typing (MLST): MLST testing was performed as originally described [12]. The sequences of the 7 housekeeping genes were compared with previously observed allelic sequences and assigned a ST using the $S$. suis MLST database (http://ssuis.mlst.net). The isolates were grouped with all isolates present in the $S$. suis database using the eBURST algorithm (http://eburst.mlst.net) [6].

Statistical analysis: In order to investigate if there are any correlation between number of resistance genes and MIC of the respective antibiotics, we compared the MIC of tetracycline or erythromycin between respective resistant $S$. suis groups. The tetracycline resistant strains were grouped into 2 groups as follows: strains carrying single tetracycline resistant gene and strains carrying 2 tetracycline resistant genes; except for 2 erythromycin-resistant isolates, in which no erythromycin resistance gene was detected, the erythromycin resistant strains were grouped into 3 groups as follows: strains carrying single erythromycin resistant gene, strains carrying 2 erythromycin resistant genes and strains carrying 3 erythromycin resistant genes. The Kruskal-Wallis test was used for the overall comparison of the respective groups, and pair-wise comparisons were performed using Wilcoxon rank-sum tests, with Bonferroni correction for multiple testing when necessary. Statistical analysis was performed with SPSS software (version 17.0; SPSS Inc., Chicago, IL, U.S.A.). A two-tailed value of $P<0.05$ was considered to be significant in this study.

Nucleotide sequence accession numbers: The nucleo- 
Table 2. Distributions of S. suis serotypes, tetracycline and erythromycin resistance genes

\begin{tabular}{|c|c|c|c|c|c|c|c|c|c|c|c|c|}
\hline \multirow{3}{*}{$\begin{array}{l}\text { No. of } \\
\text { sreotype }\end{array}$} & \multirow{3}{*}{$\begin{array}{l}\text { No. of } \\
\text { strains }\end{array}$} & \multicolumn{11}{|c|}{ No. of strains with tetracycline and erythromycin resistance determinants } \\
\hline & & \multicolumn{2}{|c|}{ Efflux genes } & \multicolumn{6}{|c|}{ Ribosomal Protection genes } & \multirow{2}{*}{$\begin{array}{c}\begin{array}{c}\text { rRNA } \\
\text { methyl- } \\
\text { ase gene }\end{array} \\
\begin{array}{c}\text { erm } \\
\text { (B) }\end{array}\end{array}$} & \multicolumn{2}{|c|}{ Efflux genes } \\
\hline & & $\begin{array}{c}\text { tet } \\
(40)\end{array}$ & $\begin{array}{l}\text { tet } \\
(\mathrm{L})\end{array}$ & $\begin{array}{l}\text { tet } \\
(\mathrm{M})\end{array}$ & $\begin{array}{l}\text { tet } \\
(\mathrm{O})\end{array}$ & $\begin{array}{l}\text { tet } \\
(\mathrm{S})\end{array}$ & $\begin{array}{c}\text { tet } \\
(\mathrm{W})\end{array}$ & $\begin{array}{c}\text { tet } \\
(\mathrm{O} / 32 / \mathrm{O})\end{array}$ & $\begin{array}{c}\text { tet } \\
(\mathrm{O} / \mathrm{W} / 32 / \mathrm{O})\end{array}$ & & $\begin{array}{c}m e f \\
(\mathrm{~A} / \mathrm{E})\end{array}$ & $\begin{array}{l}m s r \\
\text { (D) }\end{array}$ \\
\hline 2 & 95 & 63 & 1 & $15^{\text {b) }}$ & $78^{\mathrm{c}}$ & 1 & 2 & $1^{\text {d) }}$ & 0 & $60^{\mathrm{e})}$ & $50^{\mathrm{e})}$ & 50 \\
\hline 3 & 3 & 0 & 0 & 0 & 2 & 0 & 0 & 0 & 0 & 3 & $1^{\mathrm{f})}$ & 0 \\
\hline 4 & 2 & 0 & 0 & 0 & 2 & 0 & 0 & 0 & 0 & 2 & 0 & $\left.1^{g}\right)$ \\
\hline 5 & 3 & 0 & 0 & 1 & 1 & 0 & 0 & 0 & 1 & 3 & 0 & 0 \\
\hline 7 & 1 & 0 & 0 & 0 & 1 & 0 & 0 & 0 & 0 & 1 & 0 & 0 \\
\hline 11 & 1 & 0 & 0 & 0 & 1 & 0 & 0 & 0 & 0 & 0 & 0 & 0 \\
\hline 28 & 1 & 0 & $1^{\text {a) }}$ & 0 & 1 & 0 & 0 & 0 & 0 & 1 & 0 & 0 \\
\hline Total & 106 & 63 & 2 & 16 & 86 & 1 & 2 & 1 & 1 & 70 & 51 & 51 \\
\hline
\end{tabular}

Table 3. The correlation between number of resistance genes and MIC range

\begin{tabular}{|c|c|c|c|c|}
\hline Group & No of isolates & Tetracycline or erythromycin resistance genes ${ }^{\text {a) }}$ & Range of MIC (mg/l) & $P$-values ${ }^{\mathrm{b})}$ \\
\hline 1 & 38 & $\operatorname{tet}(\mathrm{M}), \operatorname{tet}(\mathrm{O}), \operatorname{tet}(\mathrm{W})$ or $\operatorname{tet}(\mathrm{O} / \mathrm{W} / 32 / \mathrm{O})$ & $8-32$ & $<0.001$ (group 1 vs. 2) \\
\hline 2 & 67 & $\begin{array}{l}t \operatorname{tet}(40)+\operatorname{tet}(\mathrm{O}), \operatorname{tet}(40)+\operatorname{tet}(\mathrm{O} / 32 / \mathrm{O}), \operatorname{tet}(\mathrm{M})+\operatorname{tet}(\mathrm{O}) \\
\operatorname{tet}(\mathrm{M})+\operatorname{tet}(\mathrm{S}), \operatorname{tet}(\mathrm{M})+\operatorname{tet}(\mathrm{L}) \operatorname{or} \operatorname{tet}(\mathrm{O})+\operatorname{tet}(\mathrm{L})\end{array}$ & $16-64$ & \\
\hline & & & & 1.767 (group 3 vs. 4 ) \\
\hline 3 & 18 & $\operatorname{erm}(\mathrm{B})$ & $4-512$ & $\begin{array}{l}0.543 \text { (group } 3 \text { vs. } 5) \\
\left.0.171^{\text {c) }} \text { (group } 3 \text { vs. } 4 \text { vs. } 5\right)\end{array}$ \\
\hline 4 & 2 & $\operatorname{erm}(\mathrm{B})+m e f(\mathrm{~A})$ or $\operatorname{erm}(\mathrm{B})+m s r(\mathrm{D})$ & $256-512$ & 0.570 (group 4 vs. 5 ) \\
\hline 5 & 50 & $e r m(\mathrm{~B})+m e f(\mathrm{~A})+m s r(\mathrm{D})$ & $64-512$ & \\
\hline
\end{tabular}

a): Tetracycline or erythromycin resistance genes which could be concomitantly detected were linked with sign “+”. b): Pair-wise comparisons based on Wilcoxon rank-sum tests with Bonferroni correction for multiple testing. c): Comparison of group 3, 4 and 5 was based on KruskalWallis test.

tide sequences reported here have been submitted to the GenBank sequence database and assigned accession numbers: JQ280443-JQ280445 [tet(40)], JQ280448 [tet(L)], $\mathrm{JQ740052}[\operatorname{tet}(\mathrm{O} / 32 / \mathrm{O})], \mathrm{JQ} 740053[\operatorname{tet}(\mathrm{O} / \mathrm{W} / 32 / \mathrm{O})]$ and JQ762256 [tet $(\mathrm{S})]$.

\section{RESULTS}

Serotype and genotype of S. suis isolates: A total of 106 $S$. suis strains were isolated from diseased pigs over a threeyear period (2008-2010) in China. Serotype 2 was the most frequently observed strain $(\mathrm{n}=95)$ among these $S$. suis strains, followed by serotypes $3(n=3), 5(n=3), 4(n=2), 7(n=1), 11$ $(n=1)$ and $28(n=1)$ (Table 2). MLST results showed that 99 strains were assigned to CC1, including ST1 $(n=21)$, ST7 $(n=74)$, ST156 $(n=2)$ and ST289 $(n=2)$. Other STs were also found, such as ST28 ( $n=5$, CC28), ST29 ( $n=1$, CC25) and ST118 $(n=1)$ (Table 3). Serotype 2 was composed of strains ST1 $(n=20)$, ST7 $(n=70)$, ST28 $(n=4)$ and ST289 $(n=1)$, and significant correlations between serotype 2 and both ST7
( $P=0.017$, Fisher's exact test $)$ and $\mathrm{CC} 1 \quad(P=0.024$, Fisher's exact test) were identified.

Antimicrobial susceptibility testing: The resistance frequencies of all isolates were: $99.1 \%$ for tetracycline, $68.9 \%$ for azithromycin, $67.9 \%$ for erythromycin, $67.9 \%$ for clindamycin, $16 \%$ for trimethoprim/sulfamethoxazole, $2.8 \%$ for levofloxacin, $1.9 \%$ for chloramphenicol and $0.9 \%$ for both cefaclor and ceftriaxone. All strains were susceptible to ampicillin, penicillin, amoxicillin/K clavulanate, cefotaxime, cefuroxime cefepime, meropenem and vancomycin. 72 $(67.9 \%)$ strains were resistant to at least four antimicrobials, and the most common resistance pattern was tetracyclineazithromycin-erythromycin-clindamycin, consisting of macrolide, tetracycline and lincosamide antibiotics (data not shown).

Detection of tetracycline and erythromycin resistance genes: The distributions of tetracycline and erythromycin resistance genes among isolates of $S$. suis are shown in Table 2. The tetracycline ribosomal protection genes $[\operatorname{tet}(\mathrm{M}), \operatorname{tet}(\mathrm{O})$, $\operatorname{tet}(\mathrm{S})$ and $\operatorname{tet}(\mathrm{W})]$, and efflux genes $[\operatorname{tet}(\mathrm{L})$ and $\operatorname{tet}(40)]$, 
and the erythromycin methylase gene $[\operatorname{erm}(\mathrm{B})]$, and efflux genes $[m e f(\mathrm{~A} / \mathrm{E})$ and $m s r(\mathrm{D})]$ were detected. Amplicons could be obtained using full-length $\operatorname{tet}(\mathrm{O})$ primers (tetOFF2 and tetOFF3) in 2 isolates in which amplicons could not be obtained using primers internal to $\operatorname{tet}(\mathrm{O})(\operatorname{tet}(\mathrm{O})-\mathrm{F}$ and tet $(\mathrm{O})-\mathrm{R})$, which indicated the presence of mosaic genes. The presence of mosaic genes tet $(\mathrm{O} / \mathrm{W} / 32 / \mathrm{O})(\mathrm{GenBank}$ accession no. JQ740053) and tet $(\mathrm{O} / 32 / \mathrm{O})(\mathrm{GenBank}$ accession no. JQ740052) was confirmed by the sequencing of PCR products. Except for two erythromycin-resistant isolates, in which no erythromycin resistance gene was detected, all tetracycline- and erythromycin-resistant isolates were detected with at least one associated resistance gene, and at least 2 tetracycline or erythromycin resistance genes were concomitantly detected in 67 and 52 isolates, respectively.

Based on the PCR results, we found several tandem organizations of antibiotic resistance genes (Table 2). For example, the tet(40) gene was located in tandem with the tet $(\mathrm{O})$ gene in 62 out of $86 \operatorname{tet}(\mathrm{O})$ positive isolates and with the $\operatorname{tet}(\mathrm{O} / 32 / \mathrm{O})$ gene in $1 / 1 \operatorname{tet}(\mathrm{O} / 32 / \mathrm{O})$ positive isolate; the tet $(\mathrm{L})$ gene was located in tandem with the tet $(\mathrm{M})$ gene in $1 / 16$ tet $(\mathrm{M})$ positive isolates. Additionally, the $m s r(\mathrm{D})$ gene was located in tandem with the mef(A/E) in 50/50 mef $(\mathrm{A} / \mathrm{E})$ positive isolates.

Association between number of resistance genes and MICs: Pair-wise comparisons revealed that the MICs to tetracycline for strains containing two resistance genes were higher than for strains possessing single resistance gene $(P<0.001$, Wilcoxon rank-sum test, Table 3$)$. However, there were no significant differences in the MICs among the 3 groups of strains containing one or more erythromycin resistance genes ( $P=0.171$, Kruskal-Wallis test, Table 3 ).

\section{DISCUSSION}

S. suis infections are causing important economic losses to the swine industry worldwide and pose a significant threat to public health $[20,25]$. In this study, we determined the serotypes and sequence types, performed antimicrobial susceptibility assays on and identified tetracycline and erythromycin resistance determinants of S. suis to demonstrate the current epidemiological status of $S$. suis isolated from diseased pigs in China.

In this study, we found that serotype 2 was the most frequently isolated serotype, which was consistent with previous reports in the same country $[13,24]$, but differed from studies performed in North America [7,9]. We showed that most $S$. suis serotype 2 strains from diseased pigs in China belong to ST1 and ST7, which differed from another study performed in North America, in which most $S$. suis serotype 2 strains belonged to ST28 and ST25, and only a small percentage $(5 \%)$ of isolates were assigned to ST1 [8]. ST1 was the major ST identified and has resulted in the deaths of 3 out of 20 patients in northern Thailand [21]. ST7 caused the human STSS outbreaks in the Sichuan and Jiangsu provinces of China [26]. Generally, CC1 was strongly associated with isolates from septicemia, meningitis, and arthritis, and is responsible for most human infections [12]. Our results suggest that CC1 is still widespread in China and poses a considerable threat to public health; moreover, continuous surveillance of S. suis is important to guide current and future preventative action against the infection of S. suis in pigs and humans.

Most strains were resistant to tetracycline, azithromycin, erythromycin and clindamycin. This outcome might be explained by the intensive use of tetracyclines, macrolides and lincosamides, alone or in combination, for prophylaxis or treatment in pig breeding in China, which could provide the selective pressure needed for antibiotic-resistant bacteria to develop and spread. Other studies also demonstrated that resistance to tetracycline, erythromycin and clindamycin was common in S. suis of animal origin [18, 23, 27]. Tetracycline resistance was found to be common among the human isolates obtained from the Chinese outbreak in 2005 [26], and 6/7 S. suis human isolates were resistant to both erythromycin and clindamycin in Japan [2]. As $S$. suis infection in humans is associated with exposure to pigs or contaminated pork [25], the antimicrobial susceptibility of $S$. suis isolated from humans might be affected by antibiotic usage during animal production.

Multiple tetracycline- or erythromycin-resistant determinants could be detected in this study, and more than half of the strains possessed at least 2 tetracycline- or erythromycinresistant determinants. Notably, we found that tetracycline or erythromycin efflux genes, such as tet(40), mef(A/E) and $m s r(\mathrm{D})$, were prevalent in $S$. suis. The tetracycline efflux gene tet(40) was first reported to be located in tandem with tet $(\mathrm{O} / 32 / \mathrm{O})$ in the human gut firmicute bacterium $C$. saccharolyticum K10 [11]. While most previous studies found that rRNA methylase was the main mechanism involved in erythromycin resistance in $S$. suis $[10,18]$, the efflux gene $m e f(\mathrm{~A} / \mathrm{E})$ has only occasionally been reported [3]. Thus, our study suggests that efflux could be another prevalent tetracycline and erythromycin resistance mechanism. Strains carrying two tetracycline resistance genes were likely to be associated with a higher MIC to tetracycline than to those carrying a single tetracycline resistance gene. However, there were no significant differences in the MICs among groups of strains containing one or more erythromycin resistance genes. This result might be due to different levels of erythromycin resistance gene expression $[1,19]$.

In conclusion, the results of this study indicate that $S$. suis isolated from diseased pigs in China is less diverse and multi-drug resistant. Multiple tetracycline- or erythromycinresistant determinants contributed to antibiotic resistance in $S$. suis, and efflux could be another prevalent tetracycline and erythromycin resistance mechanism involved.

ACKNOWLEDGMENTS. This work was supported by the National Basic Research Program (973) of China (2012CB518805), the High-Tech Research \& Development Program (863) of China (2011AA10A210), and the Chinese Major Special Science and Technology Project (2012ZX10004214). 


\section{REFERENCES}

1. Ambrose, K. D., Nisbet, R. and Stephens, D. S. 2005. Macrolide efflux in Streptococcus pneumoniae is mediated by a dual efflux pump (mel and mef) and is erythromycin inducible. Antimicrob. Agents Chemother. 49: 4203-4209. [Medline] [CrossRef]

2. Chang, B., Wada, A., Ikebe, T., Ohnishi, M., Mita, K., Endo, M., Matsuo, H., Asatuma, Y., Kuramoto, S., Sekiguchi, H., Yamazaki, M., Yoshikawa, H., Watabe, N., Yamada, H., Kurita, S., Imai, Y. and Watanabe, H. 2006. Characteristics of Streptococcus suis isolated from patients in Japan. Jpn. J. Infect. Dis. 59: 397-399. [Medline]

3. Chu, Y. W., Cheung, T. K., Chu, M. Y., Tsang, V. Y., Fung, J. T., Kam, K. M. and Lo, J. Y. 2009. Resistance to tetracycline, erythromycin and clindamycin in Streptococcus suis serotype 2 in Hong Kong. Int. J. Antimicrob. Agents 34: 181-182. [Medline] [CrossRef]

4. CLSI. 2008. Performance Standards for Antimicrobial Disk and Dilution Susceptibility Tests for Bacteria Isolated from Animals: Approved Standards, 2nd ed., CLSI Document M31-A3.

5. Daly, M. M., Doktor, S., Flamm, R. and Shortridge, D. 2004. Characterization and prevalence of MefA, MefE, and the associated $m s r(\mathrm{D})$ gene in Streptococcus pneumoniae clinical isolates. J. Clin. Microbiol. 42: 3570-3574. [Medline] [CrossRef]

6. Feil, E. J., Li, B. C., Aanensen, D. M., Hanage, W. P. and Spratt, B. G. 2004. eBURST: inferring patterns of evolutionary descent among clusters of related bacterial genotypes from multilocus sequence typing data. J. Bacteriol. 186: 1518-1530. [Medline] [CrossRef]

7. Fittipaldi, N., Fuller, T. E., Teel, J. F., Wilson, T. L., Wolfram, T. J., Lowery, D. E. and Gottschalk, M. 2009. Serotype distribution and production of muramidase-released protein, extracellular factor and suilysin by field strains of Streptococcus suis isolated in the United States. Vet. Microbiol. 139: 310-317. [Medline] [CrossRef]

8. Fittipaldi, N., Xu, J., Lacouture, S., Tharavichitkul, P., Osaki, M., Sekizaki, T., Takamatsu, D. and Gottschalk, M. 2011. Lineage and virulence of Streptococcus suis serotype 2 isolates from North America. Emerg. Infect. Dis. 17: 2239-2244. [Medline] [CrossRef]

9. Gottschalk, M., Lacouture, S., Bonifait, L., Roy, D., Fittipaldi, N. and Grenier, D. 2012. Characterization of Streptococcus suis isolates recovered between 2008 and 2011 from diseased pigs in Quebec, Canada. Vet. Microbiol. 162: 819-825.

10. Hoa, N. T., Chieu, T. T., Nghia, H. D., Mai, N. T., Anh, P. H., Wolbers, M., Baker, S., Campbell, J. I., Chau, N. V., Hien, T. T., Farrar, J. and Schultsz, C. 2011. The antimicrobial resistance patterns and associated determinants in Streptococcus suis isolated from humans in southern Vietnam, 1997-2008. Bmc Infect. Dis. 11: 6. [Medline] [CrossRef]

11. Kazimierczak, K. A., Rincon, M. T., Patterson, A. J., Martin, J. C., Young, P., Flint, H. J. and Scott, K. P. 2008. A new tetracycline efflux gene, tet $(40)$, is located in tandem with $\operatorname{tet}(\mathrm{O} / 32 / \mathrm{O})$ in a human gut firmicute bacterium and in metagenomic library clones. Antimicrob. Agents Chemother. 52: 4001-4009. [Medline] [CrossRef]

12. King, S. J., Leigh, J. A., Heath, P. J., Luque, I., Tarradas, C., Dowson, C. G. and Whatmore, A. M. 2002. Development of a multilocus sequence typing scheme for the pig pathogen Streptococcus suis: identification of virulent clones and potential capsular serotype exchange. J. Clin. Microbiol. 40: 3671-3680. [Medline] [CrossRef]

13. Li, L. L., Liao, X. P., Sun, J., Yang, Y. R., Liu, B. T., Yang, S. S., Zhao, D. H. and Liu, Y. H. 2012. Antimicrobial Resistance,
Serotypes, and Virulence Factors of Streptococcus suis Isolates from Diseased Pigs. Foodborne Pathog. Dis. 9: 583-588. [Medline] [CrossRef]

14. Lun, Z. R., Wang, Q. P., Chen, X. G., Li, A. X. and Zhu, X. Q. 2007. Streptococcus suis: an emerging zoonotic pathogen. Lancet Infect. Dis. 7: 201-209. [Medline] [CrossRef]

15. Malhotra-Kumar, S., Lammens, C., Piessens, J. and Goossens, H. 2005. Multiplex PCR for simultaneous detection of macrolide and tetracycline resistance determinants in streptococci. Antimicrob. Agents Chemother. 49: 4798-4800. [Medline] [CrossRef]

16. Ng, L. K., Martin, I., Alfa, M. and Mulvey, M. 2001. Multiplex PCR for the detection of tetracycline resistant genes. Mol. Cell. Probes 15: 209-215. [Medline] [CrossRef]

17. Patterson, A. J., Rincon, M. T., Flint, H. J. and Scott, K. P. 2007. Mosaic tetracycline resistance genes are widespread in human and animal fecal samples. Antimicrob. Agents Chemother. 51: 1115-1118. [Medline] [CrossRef]

18. Princivalli, M. S., Palmieri, C., Magi, G., Vignaroli, C., Manzin, A., Camporese, A., Barocci, S., Magistrali, C. and Facinelli, B. 2009. Genetic diversity of Streptococcus suis clinical isolates from pigs and humans in Italy (2003-2007). Euro. Surveill. 14: 193310. [Medline]

19. Rosato, A., Vicarini, H. and Leclercq, R. 1999. Inducible or constitutive expression of resistance in clinical isolates of streptococci and enterococci cross-resistant to erythromycin and lincomycin. J. Antimicrob. Chemother. 43: 559-562. [Medline] [CrossRef]

20. Staats, J. J., Feder, I., Okwumabua, O. and Chengappa, M. M. 1997. Streptococcus suis: past and present. Vet. Res. Commun. 21: 381-407. [Medline] [CrossRef]

21. Takeuchi, D., Kerdsin, A., Pienpringam, A., Loetthong, P., Samerchea, S., Luangsuk, P., Khamisara, K., Wongwan, N., Areeratana, P., Chiranairadul, P., Lertchayanti, S., Petcharat, S., Yowang, A., Chaiwongsaen, P., Nakayama, T., Akeda, Y., Hamada, S., Sawanpanyalert, P., Dejsirilert, S. and Oishi, K. 2012. Population-Based Study of Streptococcus suis Infection in Humans in Phayao Province in Northern Thailand. PLoS One 7: e31265. [Medline] [CrossRef]

22. Tang, Y., Zhao, H., Wu, W., Wu, D., Li, X. and Fang, W. 2011. Genetic and virulence characterization of Streptococcus suis type 2 isolates from swine in the provinces of Zhejiang and Henan, China. Folia Microbiol. (Praha) 56: 541-548. [Medline] [CrossRef]

23. Vela, A. I., Moreno, M. A., Cebolla, J. A., Gonzalez, S., Latre, M. V., Dominguez, L. and Fernandez-Garayzabal, J. F. 2005. Antimicrobial susceptibility of clinical strains of Streptococcus suis isolated from pigs in Spain. Vet. Microbiol. 105: 143-147. [Medline] [CrossRef]

24. Wei, Z., Li, R., Zhang, A., He, H., Hua, Y., Xia, J., Cai, X., Chen, H. and Jin, M. 2009. Characterization of Streptococcus suis isolates from the diseased pigs in China between 2003 and 2007. Vet. Microbiol. 137: 196-201. [Medline] [CrossRef]

25. Wertheim, H. F., Nghia, H. D., Taylor, W. and Schultsz, C. 2009. Streptococcus suis: an emerging human pathogen. Clin. Infect. Dis. 48: 617-625. [Medline] [CrossRef]

26. Ye, C., Bai, X., Zhang, J., Jing, H., Zheng, H., Du, H., Cui, Z., Zhang, S., Jin, D., Xu, Y., Xiong, Y., Zhao, A., Luo, X., Sun, Q., Gottschalk, M. and Xu, J. 2008. Spread of Streptococcus suis sequence type 7, China. Emerg. Infect. Dis. 14: 787-791. [Medline] [CrossRef]

27. Zhang, C., Ning, Y., Zhang, Z., Song, L., Qiu, H. and Gao, H. 2008. In vitro antimicrobial susceptibility of Streptococcus suis strains isolated from clinically healthy sows in China. Vet. Microbiol. 131: 386-392. [Medline] [CrossRef] 